\title{
Physico Chemical Assessment of Bore Water in Muthupet Areas of Thiruvarur District, Tamil Nadu, India
}

\author{
Sujatha. S, Sujitha. K \\ Department of Chemistry, Sengamala Thayaar Educational Trust Women's College, \\ Mannargudi, Thiruvarur, Tamil Nadu, India
}

\begin{abstract}
Water is the major source for the survival of living things. Due to increased human activities, contaminates in the water can affect the water quality. In turn, this can lead to public health problems. The causes of water pollution include a wide range of chemicals and pathogens as well as physical parameters. The Physico chemical characteristics of water vary depending on the source and human activities. The Immediate Sea near the shore gets pollute to a variety of activities along the coast. The people must be educated to know the problem arising due to water pollution. Hence the present study investigates the Physico chemical characteristics of bore water in Muthupet Areas. Samples of bore water were collected and analyzed. The result was compared with standards and provides valuable suggestion and recommendation for water management.
\end{abstract}

Keyword: Environment, Water pollution, Physico chemical parameters, water quality

\section{INTRODUCTION}

Ground water is water located below the ground surface. Ground water starts as rain and flows underground for long periods of time through aquifers. People drink ground water with water wells. They drill wells deep below the surface. Then in the aquifer, the ground water stored inside will be pumped up and used. In many parts of the world today ground water is the only source of fresh water [13]. Ground water is said to be the safest water for drinking and domestic purposes [8].

By the enormous and rapid growth of various industries, it is fled that several environment, water pollution has been result in by introduction of extraneous matter in solid, liquid or gaseous forms which leads to hazardous to the society. Pollution from land based activities includes spilling from sewage effluents from a variety of industries. Most of the rivers which discharge large quantities of water in to the coastal marine environment has long been used as a site for the disposal of waste. The coastal areas are affected by the discharge of sewage generated by the habitations located nearby also.

Providing clean and safe water is the major challenge with the increasing industrialization and globalization [16] .An understanding of water chemistry is the bases of the knowledge of multi dimensional aspect of aquatic environment chemistry. The quality of water is of vital concern for the mankind [12]. Water quality refers to the chemical, physical and biological and radiological characteristics of water. It is most frequently used by reference to a set of standards against which compliance, generally achieved through treatments of water, can be assessed.

Various treatment methods are adopted to raise the quality of drinking water [11] water is the most critical resource of our life. According to $\mathrm{W} \mathrm{H} \mathrm{O}$ "access to safe drinking water is essential to health, a basic human right and a component of effective policy for health protection". Hence it is required to analyze the water before using it.

\section{EXPERIMENTAL METHODS}

\section{Sampling Technique}

The samples were collected in a previously washed and dried high grade plastic containers from the bore wells of different areas. After filling the container before it was closed, recorded the sample temperature by using mobile thermometer and it was closed immediately. Then the samples were preserved to 
International Journal of Trend in Scientific Research and Development (IJTSRD) ISSN: 2456-6470

resist the changes that may occur before analysis. The samples were collected during the month of January 2018 .

\section{Physic chemical analysis}

The samples collected were analyzed for important parameters such as $\mathrm{p}^{\mathrm{H}}$, Electrical conductivity, The Total dissolved solids, Total hardness, Chloride, Sulfate, and Alkalinity. $\mathrm{p}^{\mathrm{H}^{\mathrm{V}}}$ and Conductivity was directly determined by using digital $\mathrm{p}^{\mathrm{H}}$ meter and conductivity meter. Titrimetric method was used for the determination of alkalinity and gravimetric method for Total dissolved solid and Total suspended solids. Chloride was estimated by Mohr's method. Sulfate was estimated using Gravimetric method. Total hardness was determined by EDTA titrimetric method.
Table: 1 Selected Sampling Stations Sample No Name of the stations

\begin{tabular}{|l|l|}
\hline 1 & Thillaivizagam \\
\hline 2 & Caviler \\
\hline 3 & Muthupet \\
\hline 4 & Palaver \\
\hline 5 & Sithamalli \\
\hline 6 & Melanammangkurichi \\
\hline 7 & Upper \\
\hline 8 & Karaiyankadu \\
\hline 9 & Sembadavankadu \\
\hline 10 & Aalangadu \\
\hline
\end{tabular}

Table: 2 Drinking water standards

\begin{tabular}{|c|c|c|c|c|c|}
\hline \multirow[b]{2}{*}{ S. No } & \multirow[b]{2}{*}{ Parameters } & \multicolumn{2}{|c|}{ BIS ( $10500 ; 2012)$} & \multicolumn{2}{|r|}{ WHO } \\
\hline & & $\begin{array}{c}\text { Desirable } \\
(\mathrm{ppm})\end{array}$ & $\begin{array}{l}\text { Maximum Permissible } \\
(\mathrm{ppm})\end{array}$ & $\begin{array}{c}\text { Desirable } \\
(\mathrm{ppm})\end{array}$ & $\begin{array}{l}\text { Maximum Permissible } \\
(\mathrm{ppm})\end{array}$ \\
\hline 1 & $\mathrm{p}^{\mathrm{H}}$ & $6.5-8.5$ & $6.5-9.2$ & $7-8.5$ & $6.5-9.2$ \\
\hline 2 & TDS & 500 & 2000 & 8 & - \\
\hline 3 & Total hardness & 200 & 600 ind intert & 300 & 600 \\
\hline 4 & Calcium & 75 & 200 searchand & 75 & 200 \\
\hline 5 & Magnesium & 30 & 100 eveloniment & 50 & 150 \\
\hline 6 & Sulfate & 200 & 400 & 200 & 400 \\
\hline 7 & Total Alkalinity & 200 & $600 \mathrm{~N}: 2456=6470$ & $300+0$ & 600 \\
\hline 8 & Chloride & 250 & 1000 & 250 & 1000 \\
\hline
\end{tabular}

Table: 3 Drinking water standard (EPA)

\begin{tabular}{|l|l|l|}
\hline S. No & Parameters & United State - Environmental Protection Agency \\
\hline 1 & $\mathrm{p}^{\mathrm{H}}$ & $6.0-8.5$ \\
\hline 2 & TS & 550 \\
\hline 3 & TDS & 500 \\
\hline 4 & TSS & 50 \\
\hline 3 & Total hardness & 300 \\
\hline 4 & Calcium & 200 \\
\hline 5 & Magnesium & 100 \\
\hline 6 & Chloride & 250 \\
\hline 7 & Sulfate & 250 \\
\hline 8 & Alkalinity & 33 \\
\hline 9 & Dissolved $\mathrm{CO}_{\underline{\underline{z}}}$ & Less or more than 10 \\
\hline
\end{tabular}


Table: 4 Physical Characteristics

\begin{tabular}{|l|l|l|l|l|}
\hline Sample No & Color & Odor & $\mathbf{p}^{\mathbf{H}}$ & $\begin{array}{c}\text { Electrical Conductivity } \\
\text { (m. mhos) }\end{array}$ \\
\hline 1 & Colorless & Colorless & 8.15 & 0.20 \\
\hline 2 & Colorless & Colorless & 7.13 & 0.92 \\
\hline 3 & Colorless & Colorless & 8.15 & 0.21 \\
\hline 4 & Colorless & Colorless & 7.801 & 1.18 \\
\hline 5 & Colorless & Colorless & 8.42 & 0.33 \\
\hline 6 & Colorless & Colorless & 8.26 & 0.22 \\
\hline 7 & Colorless & Colorless & 7.53 & 1.22 \\
\hline 8 & Colorless & Colorless & 7.80 & 0.25 \\
\hline 9 & Colorless & Colorless & 6.93 & 2.16 \\
\hline 10 & Colorless & Colorless & 8.75 & 0.33 \\
\hline
\end{tabular}

Table: 5 Chemical Characteristics

\begin{tabular}{|l|c|c|c|c|c|c|c|c|c|c|}
\hline Parameters ( ppm ) & $\mathbf{S}_{1}$ & $\mathbf{S}_{2}$ & $\mathrm{~S}_{3}$ & $\mathrm{~S}_{4}$ & $\mathrm{~S}_{5}$ & $\mathbf{S}_{6}$ & $\mathbf{S}_{7}$ & $\mathbf{S}_{8}$ & $\mathbf{S}_{9}$ & $\mathbf{S}_{10}$ \\
\hline TS & 370 & 800 & 550 & 337 & 500 & 255 & 158 & 337 & 304 & 220 \\
\hline TDS & 970 & 451 & 100 & 413 & 940 & 760 & 101 & 713 & 137 & 770 \\
\hline TSS & 570 & 349 & 450 & 378 & 30 & 535 & 57 & 378 & 167 & 990 \\
\hline Total hardness & 324 & 512 & 403 & 280 & 260 & 225 & 217 & 280 & 628 & 512 \\
\hline Calcium & 61 & 199 & 59 & 51 & 69 & 40 & 89 & 57 & 170 & 261 \\
\hline Magnesium & 241 & 313 & 344 & 229 & 201 & 185 & 128 & 229 & 458 & 464 \\
\hline Chloride & 298 & 7804 & 402 & 167 & 173 & 1209 & 202 & 1017 & 574 & 184 \\
\hline Sulfate & 565 & 302 & 808 & 120 & 164 & 315 & 606 & 242 & 506 & 256 \\
\hline Dissolved $\mathrm{CO}_{\underline{\underline{z}}}$ & 86 & 246 & 104 & 172 & 72 & 102 & 242 & 172 & 735 & 107 \\
\hline Alkalinity & 197 & 487 & 208 & 580 & 201 & 399 & 353 & 580 & 479 & 641 \\
\hline
\end{tabular}

\section{RESULTS AND DISCUSSION}

In order to assess the water quality of some locations, need to be analyzed the various Physico -Chemical parameters. However certain parameters are of special importance and deserve frequent attention. These results were compared with standard specifications such as BIS, WHO, US-EPA.

\section{$\mathbf{P}^{\mathbf{H}}$}

In the present study $\mathrm{P}^{\mathrm{H}}$ recorded in the range from 6.93 to 8.75.but desirable limit is up to 8.5 in all standards. For all samples values were in permissible limit according to all standards except sample 10 indicating slightly alkaline nature.

\section{Electrical conductivity}

It is actually measure of the ionic activity of a solution. The amount and natures of many dissolved substances influence their ability to electrical conductance [13]. Electrical conductivity value ranged from 0.20 to 1.22 memos. EC is the most important parameter to determine salinity hazard and fitness for ground water for agriculture purpose. Absolute pure water is a poor conductor of electricity. All water samples showed higher conductivity values.

\section{Total dissolved and Total suspended solids}

It indicates the salinity of water. Electrical conductivity and Total dissolved solids are interrelated. For the samples 1, 5, 6, 8, and 10 TDS values were higher than in all standards. TSS values of all samples were higher than EPA. TDS value above the permissible limit causes gastro intestinal irritation. 


\section{Total hardness}

Hardness is due to the presence of Calcium, Magnesium, Chloride and sulfate ions. The maximum desirable limit is $300-600 \mathrm{ppm}$ (WHO). Total hardness of $4,5,6,7$, and 8 sample values were in the permissible limit. Sample 1, 2 3, and 10 were within the maximum desirable limit. Sample 9 values were higher than all Standards. Hardness leads to skin irritation and poor lathering with soap.

\section{Sulfate}

Sulfate can be found in almost all natural water. It is one of the major dissolved components of rain. High concentration of sulfate in us can have laxative effect. Sulfate gives a bitter or medicinal taste to water. High concentration of sulfate can experience a Dehydration and Diarrhea. Sulfate values of sample $2,4,5,6,8$ and 10 values were near in the permissible limit according to all standards. Sample 1, 3, 7, 9 sulfate value were higher in all standards.

\section{Chloride}

Chloride is an essential electrolyte located in all body fluids responsible for maintaining acid/base balance, transmitting nerve impulses and regulating fluid in and out of cells. Although chlorides are harmless at low level. EPA recommends no higher than $250 \mathrm{ppm}$. At level greater than this sodium chloride can complicate existing heart problems and contribute high blood pressure when ingested in excess. Sample 2, 6, 8 chloride values were higher than in EPA Standard.

\section{Dissolved Carbon dioxide}

Natural water contains Dissolved Carbon di oxide. The Dissolved Carbon dioxide is often contributor to the acidity leads to corrosion. In the present study, The Dissolved CO2 of all samples was higher than all Standards.

\section{CONCLUSION}

The Physico Chemical assessment of bore water samples in selected Muthupet areas of Thiruvarur District Tamil Nadu, investigated results shows that sample 2, 4, 5, and 7 only were used for drinking purpose. Sample 1, 3, 6, 8, 9.and 10 was not used for drinking purpose. This study was to provide information useful for necessary pre treatment methods such as Reverse Osmosis, Distillation and Deionization by Ion exchange be used before using the water from bore well for Human Consumption.

\section{REFERENCES}

1. Manivasakam, N., Physico chemical examination of water sewage industrial effluent. Pragati Prakasan (1984)

2. K. K Saxeena, K D Gupta, Text book of practical chemistry, University book house. Ltd, India, (2004)

3. Indian Standard for drinking water Specification (BIS) IS 10500:2012

4. Coastal area Management, Tamil Nadu, State action plan for climate change, WWW. Environment. tn.nic.in

5. Vasanthi, P., Sukumaran, M., Physico chemical analysis of coastal water of Tamil Nadu, International journal of Zoology Studies, 2(5):1521(2017)

6. Shymala, R., Shanthi, M., and Lalitha , P., Physico chemical analysis of bore water samples of Telumgupalayam area in Coimbatore District, E. Journal of chemistry, 5(4): 924-929 (2008)

7. Ramadevi, P., Subramaniyan, G., Pitchammal, V., and Ramanatha, R., T he study of water qualityof Ponnamaravathy in Pudukkottai District, TamilNadu, Nature environment and pollution Technology, 8(1): 91-94 (2009)

8. Suresh, T., N. M. Kottureshwara, Asssessment of ground water quality of bore well water of Hospat Taluk Region, Karnataka India, Rasyan J. Chem, 2 (1): 221-233

9. APHA, Standard methods for the examination of water and waste water, $18^{\text {th }}$ edition, American Public Health Association, Washington, DC, 1998

10. Ignatius Navis Karthika ., M. S ., Dheenadayalan., Physico chemical study of ground water quality at selected locations in Periyakulam Theni District, TamilNadu , India, Science Direct, 5(1), 424-428, (2018)

11. Bhalme, S. P., Dr. P. B Nagarnaik ., Analysis of Drinking water of Different places - A Review, I international journal of Engineering Research and Applications, 2(3): 3255-3158 (2012)

12. Dr. C. Nagamani, and Dr. c. Saraswathi Devi., International Journal of Scientific \& Engineering Research, 6(1) (2015)

13. Syam Kumar Bariki, Byragi Reddy., J. Geetha Saramanda., Assessment of Physico chemical 
quality of Drinking water in Arakku Valley Mandal of Vishagapattinam District AP, India, The International Journal of Science and Technology.

14. A. LAMIKARAN, Essential microbiology for students and practitioners of Pharmacy, Medicine and microbiology, $2^{\text {nd }}$ edition, Amkra books, 1999.

15. Venkatramanan. S., S. Y. Chung, Ramkumar. T, Rajesh. R, G. Gnanachandrasamy, Assessment of ground water quality using GIS AND CCMEWQI Techniques-A case study of thiruthuraipoondi deltaic region, Tamil Nadu, Desalination and water treatment, 57(2016) 12058-12073

16. Nidhi Jain, Physico chemical Assessment of water quality in one part of Hinjeevadi, Pune, Maharastra, India Hydroxy: current Research, 9 (1): 291.

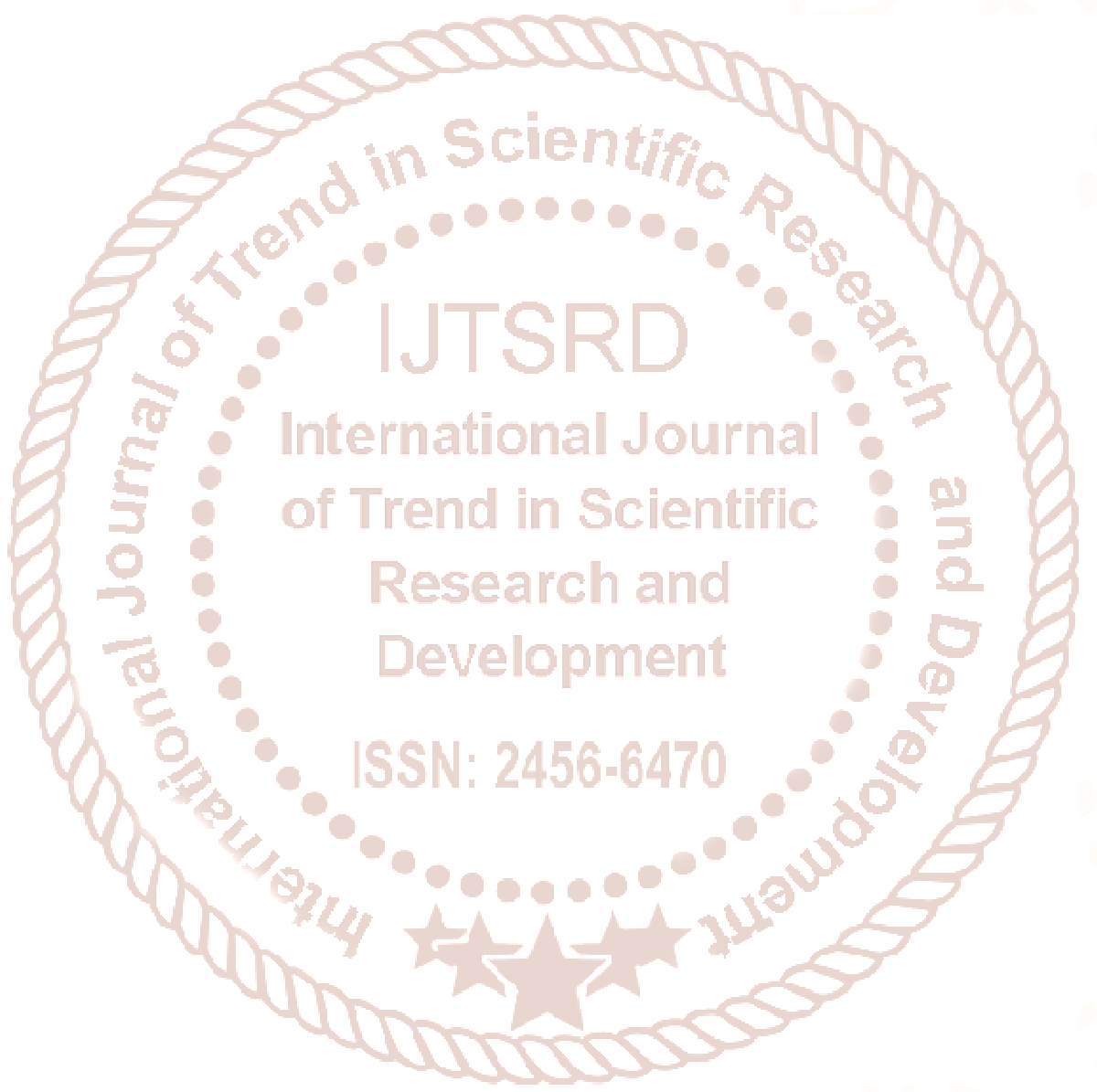

